\title{
Mechanical Properties of Rice Husks Fiber Reinforced Polyester Composites
}

\author{
I Wayan Surata, I Gusti Agung Kade Suriadi, and Krissanti Arnis
}

\begin{abstract}
Indonesia as a tropical agricultural country has great potential to develop and utilize fiber derived from agricultural waste. Rice husks are an important by-product of rice milling process that can be used as reinforcement in composite products. The purpose of this study was to examine the mechanical properties of rice husks fiber polyester composites. Composites were produced with unsaturated polyester resin as the matrix and rice husks as fiber. The matrix type is polyester Yukalac $157 \mathrm{BQTN}$, and methyl ethyl ketone peroxide as catalyst. Composites were made by hand lay-up techniques, with the variation of fiber weight fraction $20,30,40$ and $50 \%$. Tensile test specimens were made according to the ASTM D3039, and flexural test specimens according to the ASTM D790M. The results showed that the tensile and flexural strength of the composites increased when the fiber weight fraction increased.
\end{abstract}

Index Terms-Flexural strength, polyester, rice husks, tensile strength, weight fraction.

\section{INTRODUCTION}

Composite consisting of two or more materials that have different characteristics, where one serves as a binder material and the other as a fiber. The properties of the composites are strong, lightweight, corrosion resistant, wear resistant, and attractive in appearance. Many composites have been developed with various types of synthetic fibers in order to improve the mechanical properties. Currently, the type of composite tends to change from composite with synthetic fibers to natural fibers. This is because the composite with synthetic fibers such as glass fibers are not environmentally friendly, lead to problems of waste glass fiber, which can not be decomposed by nature [1]. Composites with natural fibers have many significant advantages over composites with synthetic fibers such as low cost, lighter weight, available in the form of plants or waste, non-toxicity, and does not cause skin irritation [2]. The convenience of these composites lies in the fact that the ingredients are obtained easily from natural or agricultural wastes and hence the composites can be made relative easily.

Natural fibers can be cultivated so that its availability is sustainable. However, natural fibers also have many weaknesses such as irregular dimensions, stiff, susceptible to heat, easy to absorb water, and quickly obsolete [1]. Ideally composite materials used in structures where strength to weight ratio into consideration [3]. Attempts have been made to use natural fiber composites in non-structural application.

Manuscript received December 10, 2013; revised February 21, 2014

The authors are with the Department of Mechanical Engineering, Faculty of Engineering, Udayana University, Jimbaran, Bali, 80361, Indonesia (e-mail: iwasura@gmail.com, gungsuriadi@yahoo.com).
Currently a number of automotive components previously made with glass fiber composites are now being manufactured using environmentally friendly composites. The use of natural fibers in automotive has two advantages, namely vehicles become lighter, which means improved fuel efficiency, and improved the sustainability of production because it can be cultivated [4], [5].

Indonesia as a tropical agricultural country has great potential to develop and utilize fibers derived from agricultural residues or wastes. Rice husks are amongst the typical agricultural residues, which are easily available in huge amounts generated from rice milling process. The lowland rice area in Indonesia covered 7.8 million hectares yielding 4.6 tons of mill-dry unhusked rice (milled rice) per hectare, or a total of about 35.88 million tons per year [6]. Milled rice is composed of $63 \%$ rice or the equivalent of 22.6 million tons and rice husks as much as 13.27 million tons per year. So far, the utilization of rice husks at the farmer level, especially in rural area is still limited as fuel for cooking and compost. Recently, the manufacture of composite materials from agricultural residues such as rice husks has been able to make a commercial product. Rice husks developed into a raw material to produce ash known as rice husk ash (RHA). The use of rice husk ash with an appropriate combination of the cement mixture would produce a better cement composite [7]. The researches on utilization of natural fibers are still ongoing to find ways to use lingocellulosic fibers in place of synthetic fibers as reinforcing fillers, including rice husks fibers.

Using natural fibers as reinforcing fillers facing several underlying factors related to characteristics of lignocellulosic materials, and should be concerned in order to meet the requirement of mechanical properties. Properties of composites with natural fibers are strongly influenced by the bond strength between the matrix and fibers. Binding properties between the matrix and the fiber can be improved or enhanced with a variety of chemical treatments on natural fibers such as using $\mathrm{NaOH}, \mathrm{KMnO}_{4}$, silanes, permanganate, and peroxide [8]. Alkaline treatment of kenaf and hemp fibers with polyester matrix can improve the mechanical and thermal properties of composites [9]. Jamasri et al. [1] reported that the alkaline $\mathrm{NaOH}$ treatment can improve the tensile properties of fiber composites of oil palm waste. Mechanical strength of composites reinforced with natural fibers can be improved by adjusting the ratio of the weight fraction of the fiber in the composite.

Some natural fibers such as sisal, coir, jute, hemp, flax, pineapple leaf, banana, hemp, jute, bamboo, and palm oil has been developed as a reinforcement filler to make composites [8], [10]. Mwaikambo and Ansell [11] reported that the alkali treatment with $\mathrm{NaOH}$ concentrations between 4-6\% yield 
stiffness and maximum stress on fiber hemp. Soaking time for 2 hours in the treatment of oil palm fiber with $5 \% \mathrm{NaOH}$ produced the highest tensile strength [1]. The length and diameter of the fibers also affect the mechanical strength of the composite. Ultimate tensile strength of the composite fiber banana/phenol obtained on banana fiber length of $30 \mathrm{~mm}$ [12] On hemp fiber, found the smaller the fiber diameter relationship stronger the fiber [11]. The aims of this research were to examine the tensile and flexural strength of rice husks fibers polyester composites that made by hand lay-up technique using different value of fibers weight fraction 20 , 30,40 and $50 \%$.

\section{EXPERIMENTAL METHOD}

Rice husks fibers were obtained from a local rice mill factory. Fig. 1 is the waste of rice husks around a factory that might contain many impurities such as sand, dust, bran rice, and other small particles. The research was started by selecting the rice husk waste which has average size of $7 \mathrm{~mm}$ length $\times 1.5 \mathrm{~mm}$ width $\times 0.2 \mathrm{~mm}$ thickness as shown in Fig. 2 . The selected rice husks were cleaned by washing with fresh water and dried under the sun. The fibers then were soaked in $5 \% \mathrm{NaOH}$ solution in water bath for 2 hours. The treated fibers were rinsed in fresh water to neutralize the effect $\mathrm{NaOH}$, and left to dry naturally at room temperature.

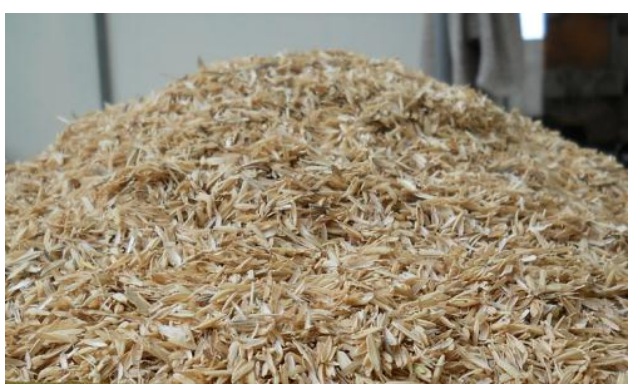

Fig. 1. Rice husks waste.

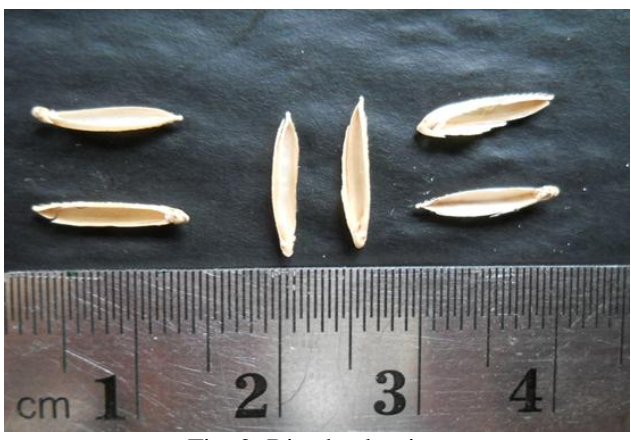

Fig. 2. Rice husks size.

Unsaturated polyester Yukalac 157 BQTN, and methyl ethyl ketone peroxide (MEKPO) were used as matrix components. Polyester and hardener $1 \%$ volume were mixed in a container and stirred to form matrix. Then the rice husks were poured gradually and stirred well to make mixture of fibers within the matrix homogeneous. Then the mixtures were poured into the mould. The composites with the variation of fiber weight fraction 20,30, 40 and 50\% were made by hand lay up techniques. The curing time was about 2 hours at temperature $65^{\circ} \mathrm{C}$. Finally, composites plates were cut into tensile and flexural specimens based on ASTM standard D3039 and D790M respectively. Tensile test was done by universal testing machine, and flexural test using three-points loading method. The data obtained were analyzed, and the result was shown as the correlation of tensile and flexural properties versus fiber weight fraction.

\section{RESULTS AND DISCUSSION}

\section{A. Tensile Properties}

The tensile strength at break for rice husks fiber composites with variation of fiber weight fractions were presented in Table I, and graphically were shown in Fig. 3.

TABLE I: TENSILE PROPERTIES OF RiCE Husks FiBER COMPOSITE

\begin{tabular}{cccc}
\hline \hline $\begin{array}{c}\text { Fiber weight } \\
\text { fraction } \\
(\%)\end{array}$ & $\begin{array}{c}\text { Tensile strength } \\
(\mathrm{MPa})\end{array}$ & Strain & $\begin{array}{c}\text { Modulus } \\
\text { elasticity } \\
(\mathrm{GPa})\end{array}$ \\
\hline 0 & 18.22 & 1.60 & 1.13 \\
20 & 32.53 & 1.22 & 2.66 \\
30 & 36.26 & 1.12 & 3.23 \\
40 & 41.06 & 1.00 & 4.10 \\
50 & 46.40 & 0.91 & 5.09 \\
\hline \hline
\end{tabular}

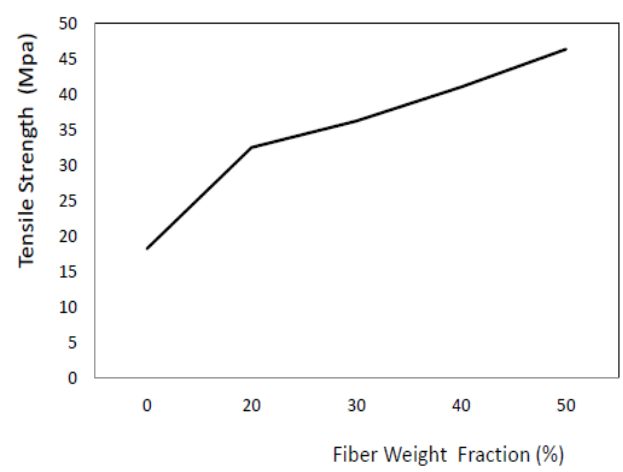

Fig. 3. Tensile strength as a function of fiber weight fraction.

It can be seen from the graph on Fig. 3 that as the fiber weight fraction increased to $20 \%$, the tensile strength shows remarkable increased. Then as the fiber weight fraction continually increased, the tensile strength of the composites slightly increased. It was clear that tensile strength of the composites increased with increasing in percentage of fiber weight fraction, and presented the highest average value of $46.40 \mathrm{MPa}$ at fiber weight fraction $50 \%$, and the lowest of $32.53 \mathrm{MPa}$ at fiber weight fraction $20 \%$. Tensile modulus also improved with increasing the fiber weight fraction in the composites, the highest average value of $5.09 \mathrm{GPa}$ at fiber weight fraction $50 \%$, and the lowest of $2.66 \mathrm{GPa}$ at fiber weight fraction $20 \%$. However, the strain of the composites decreased as the fiber weight fraction increased, with the highest average value of $1.22 \%$, at fiber weight fraction $20 \%$, and the lowest $0.91 \%$ at fiber weight fraction $50 \%$.

Hardinnawirda and Aisha [16] reported that the tensile strength of the rice husk composites moderate increased for the $25 \mathrm{wt} \%$ filler loading, the values ranged between 12-16 MPa. Meanwhile in this study the tensile strength was obtained between $32.53-36.26 \mathrm{MPa}$ at fiber weight fraction $20-30 \%$. The differences due to the alkali treatment, where 
rice husks fibers soaked in $5 \% \mathrm{NaOH}$ solution for 2 hours, resulted the rice husk has clean surface and leading to better interfacial bonding between the rice husks fiber and matrix. On contrary, Badri [17] found out that the tensile strength of rice husk fiber composite was higher than the result in this study, with average value of 86.7 MPa. The differences due to the filtering of rice husk, so the rice husk fiber became smooth. The smaller the fiber diameter increases the strength of the composites [11].

The maximum stress of the composite depends on several factors, one such factor is the weight or volume fraction of the fiber. Some studies related to this theorem in application of natural fiber have been reported. Wambua et al. [8] reported that the tensile strength and tensile modulus of natural fibers composites increased with increasing fiber volume fraction. Furthermore, Jamasri et al. [1] reported that the tensile strength and tensile modulus of oil palm fiber composite increased as the fiber weight fraction increased. Same tendency result was found in the ramie fiber composites, which the tensile strength and tensile modulus of the composites increased with increasing fiber volume fraction [13]. Joseph et al. [12] found that the tensile strength of composites increased regularly with increasing the weight fraction of banana fiber in composites. Jamasri et al. [1] and Wijang et al. [15] presented that the increasing in the fiber weight fraction were followed by increasing in tensile strength of the composite.

\section{B. Flexural Properties}

The flexural strength at break for rice husks fiber composites with variation of fiber weight fractions were presented in Table II, and graphically were shown in Fig. 4.

\section{TABLE II: FLEXURAL PROPERTIES OF RICE HUSKS FIBER COMPOSITE}

\begin{tabular}{cccc}
\hline \hline $\begin{array}{c}\text { Fiber weight } \\
\text { fraction } \\
(\%)\end{array}$ & $\begin{array}{c}\text { Flexural } \\
\text { strength } \\
(\mathrm{MPa})\end{array}$ & Strain & $\begin{array}{c}\text { Modulus } \\
\text { elasticity } \\
(\mathrm{GPa})\end{array}$ \\
\hline 0 & 82.94 & 2.90 & 2.86 \\
20 & 89.70 & 3.08 & 3.73 \\
30 & 100.03 & 2.81 & 4.55 \\
40 & 109.85 & 2.71 & 5.22 \\
50 & 118.67 & 2.30 & 6.60 \\
\hline \hline
\end{tabular}

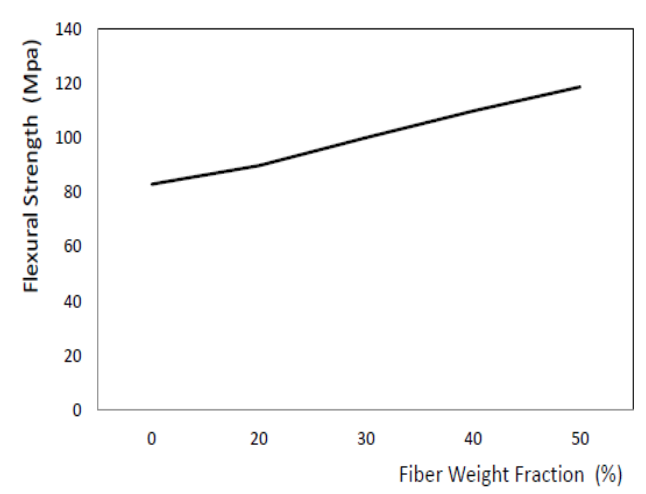

Fig. 4. Flexural strength as a function of fiber weight fraction.

From the graph Fig. 4, it was clear that flexural strength of the composites slightly increased with increasing in percentage of fiber weight fraction, and presented the highest average value of $118.67 \mathrm{MPa}$ at fiber weight fraction $50 \%$, and the lowest of $89.70 \mathrm{MPa}$ at fiber weight fraction $20 \%$. Flexural modulus also improved with increasing the fiber weight fraction in the composites, the highest average value of $6.60 \mathrm{GPa}$ at fiber weight fraction $50 \%$, and the lowest of 3.73 $\mathrm{GPa}$ at fiber weight fraction $20 \%$. However, the strain at break of the composites decreased as the fiber weight fraction increased, with the highest average value of $3.08 \%$, at fiber weight fraction $20 \%$, and the lowest $2.30 \%$ at fiber weight fraction $50 \%$.

Diharjo et al. [14] found that the flexural strength and flexural modulus of kenaf-polyester composites increased with increasing in percentage of fiber weight fraction. The same result was obtained in ramie fiber composites, where the flexural strength and flexural modulus increased linearly with increasing the volume fraction of fiber in the composites [13]. Alkalized of kenaf and hemp fiber composites gave higher flexural modulus and flexural strength compared with composites made from as-received fibers as in [9].

\section{CONCLUSION}

Mechanical properties of rice husks fiber reinforced polyester composites have been observed. The tensile strength and tensile modulus of the rice husks composites increased with increasing fibers weight fraction. The similar results were found that the flexural strength and flexural modulus also increased with increasing fibers weight fraction in the composites. Mechanical properties of rice husks fiber composites were affected by fiber fraction and alkalisation. Alkalisation caused a better interfacial bonding between rice husks fiber and polyester matrix, and yielded the improvement of the mechanical properties.

\section{ACKNOWLEDGMENT}

The authors wish to thank the Mechanical Engineering Department, Faculty of Engineering, Udayana University, Jimbaran, Bali, Indonesia, for providing the laboratory facilities to carry out the research work.

\section{REFERENCES}

[1] D. K. Jamasri and G. W. Handiko, "Studi perlakuan alkali terhadap sifat tarik komposit limbah serat sawit polyester," in Proc. 2005 SNTTM-IV Conf., 2005, G3, pp. 23-28.

[2] K. Oksman, M. Skrifvars, and J. F. Selin, "Natural fiber as reinforcement in Polylactic Acid (PLA) composites," J. Composite Sci. and Tech, vol. 63, pp. 1317-1324, 2003.

[3] R. F. Gibson, Principles of composite materials mechanics, Mc Graw-Hill Series, 1994.

[4] M. P. Westman, L. S. Fifield, K. L. Simmons, S. G. Laddha, T. A Kafentzis, "Natural fiber composites: A review," U.S. Department of Energy, Pacific Northwest National Laboratory, 2010.

[5] J. Holbery and D. Houston, "Natural-Fiber-Reinforced polymer composites in automotive applications," JOM, vol. 58, no. 11, pp. 80-86, 2006.

[6] A. Apriantono, Indonesia Strategic Vision for Agriculture and Rural Development, Jakarta, 2006.

[7] N. B. Singh, V. D. Singh, S. Rai, and S. Chaturvedi, "Effect of lignosulfonate, calcium chloride and their mixture on the hydration of RHA-blended Portland cement," Cement and Concrete Research, vol. 32, no. 3, pp. 387-392, 2002

[8] P. Wambua, J. Ivens, and I. Verpoest, "Natural fibres: Can they replace glass in fibre reinforced plastics?" Composite Science and Technology, vol. 63 , pp. $1259-1264,2003$.

[9] S. H. Azis and M. P. Ansell, "The effect of alkalization and fibre alignment on the mechanical and thermal properties of kenaf and hemp 
bast fibre composites: Part 1 - polyester resin matrix," Composites Science and Technology, vol. 64, pp. 1219-1230, 2004.

[10] K. M. M. Rao and K. M. Rao, "Extraction and tensile properties of natural fibers: Vakka, date and bamboo," Composite structures, Elsevier, 2005.

[11] L. Y. Mwaikambo and M. P. Ansell, "Hemp fibre reinforced cashew nut shell liquid composites," Composite Science and Technology, vol. 63, pp.1297-1305, 2003.

[12] S. Joseph, M. S. Sreekala, Z. Oommen, P. Koshy, and S. Thomas, "A comparison of the mechanical properties of phenol formaldehyde composites reinforced with banana fibres and glass fibres," Composites Science and Technology, vol. 62, pp. 1857-1868, 2002.

[13] I. W. Surata, N. M. Dwidiani, and P. O. Alfano, "Pengaruh fraksi volume serat terhadap sifat tarik dan lentur komposit berpenguat serat rami dengan matriks polyester," in Proc. 2012 SNTTM-XI Conf., 2012, MAT-031, pp. 1551-1555.

[14] K. Diharjo, J. Soekrisno, and H. S. B. Rochadjo, "The flexural an impact properties of random and woven kenaf fiber reinforced polyester composite," in Proc. 2005 SNTTM-IV Conf., 2005, G3, pp.13-16.

[15] W. R. Wijang and D. Ariawan, "Pengaruh Modifikasi Serat terhadap Karakteristik Komposit UPRs-Cantula," Jurnal Poros Jurusan Teknik Mesin FT-UNTAR, vol. 9, no. 3, pp. 200-206, 2006.

[16] K. Hardinnawirda and I. S. Aisha, "Effect of rice husks as filler in polymer matrix composites," Journal of Mechanical Engineering and Sciences (JMES), vol. 2, pp. 181-186, 2012.

[17] M. M. Badri, "Pengaruh pembebanan statik terhadap perilaku mekanik komposit polimer yang diperkuat serat alam," Jurnal Dinamis, vol. 2, no. 4, pp. 46-52, 2009.

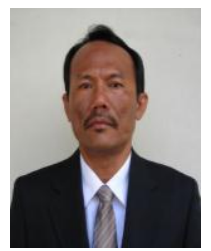

I Wayan Surata was born in Nusa Penida, Klungkung, Bali, Indonesia on July 5,1958 . He received the doctor degree in the field of Ergonomics from Udayana University, Jimbaran, Bali Indonesia in 2011. He worked as a lecturer, senior lecturer, and an assistant professor in the Department of Mechanical Engineering. Presently, he is working as an associate professor in the Department of Mechanical Engineering, Faculty of Engineering, Udayana University, Jimbaran, Bali, Indonesia. He participated in some international research collaborations such as with Toyohashi University of Technology Japan, and University of Occupational and Environmental Health Japan. His current research interests lie in the field of composites, metallurgy, renewable energy, ergonomics, and manufacturing process

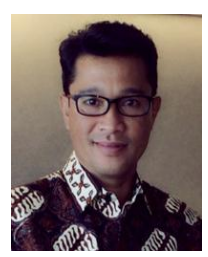

I Gusti Agung Kade Suriadi was born in Negara, Bali, Indonesia on April 9, 1966. He received his master degree in industrial engineering from Institute Technology of Sepuluh November, Surabaya, Indonesia in 2001. He worked as a lecturer, and an assistant professor in the Department of Mechanical Engineering, Faculty of Engineering, Udayana University, Jimbaran, Bali, Indonesia. His fields of research include production planning, logistics, ergonomics, and manufacturing process.

Krissanti Arnis is in the final stage in finishing her undergraduate course at the Department of Mechanical Engineering, Faculty of Engineering, Udayana University, Jimbaran, Bali Indonesia. Her research interests include composite materials, metallurgy, and manufacturing process. 